- $\quad \mathrm{V} \rightarrow \mathrm{N}$ или, другими словами, отглагольные существительные (update модернизация, обновление данных)

- $\quad \mathrm{Adj} \rightarrow \mathrm{V}$ или деадъективные глаголы (uplevel, adj — a more recent version of a program or document; $\rightarrow$ to uplevel, $\mathrm{v}$ - to install a more recent version of a program or document)

- $\quad \mathrm{N} \rightarrow \mathrm{V}$ или отыменные глаголы (position, $\mathrm{n}$ - a point of view or attitude on a certain question $\rightarrow$ to position, $\mathrm{v}$ - to explain or provide context)

3. Производные основы-сокращения. Производными основами при конверсии часто служат такие лексические единицы, которые являются следствием сокращения (усечения, аббревиация, телескопия). Например: spooling, n (simultaneous peripheral operationonline) $\rightarrow$ to spooling, v. Аббревиатуры также используются в качестве исходных основ.

4. Сложные основы. В последнее время проявляют активность модели конверсии в сфере сложных слов, а особенно модель $\mathrm{V} \rightarrow \mathrm{N}$. Примерами этому могут служить:

- $\quad$ именные основы структурного типа «основа существительного + основа существительного» (point to point, adj — pertaining to data transmission between two locations without the use of any intermediate display or computer);

- $\quad$ именные основы структурного типа «основа прилагательного + основа существительного» (to green sheet, $\mathrm{v}$ - to submit an expense for repayment);

- «основа глагола + основа существительного» (to checkpoint, $\mathrm{v}$ - to record the information about a status of a program's execution).

5. Словопроизводящие словосочетания. Build-to-order, adj — of a hardware product: manufactures or to be manufactured, following customer orders;

Проведя наше исследование, мы выявили, что наибольшую активность при словообразовании путем конверсии в компьютерной терминологии проявляют простые и аффиксальные производные основы.

$$
* * *
$$

1. Бортничук Е.Н., Василенко И.В., Пастушенко Л.П. Словообразование в современном английском языке. - Киев, 1988.

2. Заботкина В.И. Новая лексика современного английского языка. - М., 1989.

3. Пьянзина И. Н. Основы лексикологии английского языка. - Нижний Новгород, 2005.

4. Marchand H. Expansion, transposition and -derivation / H. Marchand // La Linguistique. - 1967. - Vol. 7. - P. $13-26$.

\title{
Selezneva O.N. \\ Present Indefinite, Present Continuous in expressing the future tense in the modern English language
}

Tver branch of RANEPA

(Russia, Tver)

doi: 10.18411/scienceconf-03-2021-47

idsp: scienceconf-03-2021-47

\section{Аннотация}

В статье поднимается вопрос о толковании значений презентных форм, а именно Present Indefinite, Present Continuous, в обозначении будущего времени в современном английском языке. Презентные формы являются одним из популярных средств выражения будущего, начиная с древнеанглийского и до настоящего времени. Автор статьи предполагает, что в современном английском языке презентные формы 
используются для обозначения запланированных будущих событий, в описании которых отсутствует логическая или эмоциональная оценка со стороны говорящего.

Ключевые слова: презентные формы, Present Indefinite, Present Continuous, будущее время, запланированное действие, объективная модальность.

\section{Abstract}

The article raises the question of interpreting the meanings of the present tense forms, namely Present Indefinite, Present Continuous, while expressing the future tense in the modern English language. The present tense forms have been one of the most popular means of expressing the future tense, since Old English to the present days. The author of the article suggests that in the modern English language, the present tense forms are used to denote planned future events, in the description of which there is no logical or emotional assessment on the part of the speaker.

Key words: the present tense forms, Present Indefinite, Present Continuous, the future tense, planned action, objective modality.

Since the Old English period forms of the present, i.e. Present Indefinite and Present Continuous, have been used to express the future tense. Nevertheless, in the modern English language, despite the abundance of means of expressing the future tense, the present forms in the meaning of the future are still relevant, since there is a certain similarity between the semantics of the present and future tense.

In addition to the "here and now" situation, the semantics of the present includes a description of a situation characteristic of the past, but which can potentially occur in the future. In such cases, we are not talking about the event that is taking place at a given moment of our speech, but we mean constantly occurring events, some routine actions. The very semantics of the present tense of the action allows its rethinking as the future tense of the action. That is why the forms of the verb, usually denoting actions performed in the present tense, can be used to indicate actions that will be performed in the future.

The form of the present of the planned future describes an event that does not occur in the present, but is planned, predicted, or implied by a speaker. This also shows the conjugation of the semantics of the present and the future, because the planned or predicted action is included in the course of real events. The conjugation of the semantics of the present and the future partly explains the use of the present forms in the conditional clauses - some action is planned, predicted or implied by the speaker. In addition, the action, expressed in the present forms in the conditional clauses, is the background for the main semantic message, expressed, as a rule, by using shall / will + Infinitive.

R. Quirk argues that the grammatical meaning of Present Indefinite in denoting future actions is an obvious action of the future, which acts out as an undoubted fact testifying to such a future event, which is usually associated with what is happening now or happened in the past. The form is commonly used in messages about calendar dates or to describe immutable events or agreements. Another meaning of Present Indefinite in the meaning of the future is the expression of a planned action that will occur on a schedule [8, p.48].

$\mathrm{M}$. Bloch also mentions such a meaning of the present tense form when describing the future, as an expressive transfer of the description of future actions to the plan of the present, in his terminology - "futural present": Another meaning of present forms in denoting the future tense is "the categorical attitude of the speaker regarding the performance of some action in the future" [3, p.96].

G. Weichman notes that the use of the Present Indefinite form in the meaning of the future is possible in cases where there is no doubt about the performance of an action at a particular moment in the future, in the absence of an emotional coloring of the statement [11, p.160-161].

Finally, the Present Indefinite form in the meaning of the future can be used in those cases when it comes to a future situation arising from the events of the present, or when the 
future action is predicted regardless of the will of the subject, but is based on the actions of the present (that is, the future action as one of options for the unfolding of events of the present) [10].

Some researchers, for example Yu. Stepanov [10], E. Chrysonopulo [4], G. Weichman [11] suggest that the Present Indefinite form always contains an indication of an external (in relation to the cognizing subject) source of information about the state of affairs reported in the statement, indicates a general idea of future action, and this idea does not depend on cognitive activity of a particular person. The verb which is used in the Present Indefinite form to express the future tense denotes an ordinary, traditional, habitual action performed due to a predetermined order or a certain well-known pattern.

Another form of the present tense that is used in the meaning of the future is Present Continuous, traditionally marking events that are taking place 'at the moment.' In the meaning of the future, Present Continuous can be used to describe the nearest future events "fixed arrangement, plan, or program", when expressing planned actions (often with verbs describing the transition from one state to another - arrive, come, go, stop) [8, p. 47-49].

In addition, Present Continuous in the meaning of the future is used to express plans for the future (while Future Indefinite is predictive in nature) [7, p. 87].

G. Weichmann notes that Present Continuous expresses the planned action of the near future, in terms of frequency of use, it exceeds Present Indefinite in the same meaning by 7-8 times [11, p 56].

L. Barkhudarov, D. Stelling point out that the use of the present forms in the meaning of the future gives meaning and importance to an action. Often these are the verbs of movement, arrival, departure, entry into action, implementation - go, come, arrive, leave, sail, take place, take effect. In addition, the present forms bring a categorical certainty of the expected action, which often acts out as a characteristic of a book-writing style. Researchers believe that in the Continuous form, the verb gives the sentence an emotional coloring (fear, condemnation, discontent, etc. - the invisible man is coming!) - [1, p. 193].

Summarizing the research devoted to the use of present forms in the meaning of the future, we distinguish the following connotations in the meanings of present forms:

Present Indefinite: planning, forecasting a situation, an undoubted fact of the future, calendar dates, upcoming future events, exact plans, transition from one state to another, categorical attitude, "futural present", future as a continuation of the present, future with objective modality;

Present Continuous: strictly planned action, plan, program, near future, transition from one state to another (often with verbs of movement), description of future actions in the present, lack of personal assessment of the speaker of future events, objective modality (Present Continuous when describing the future).

There are a few examples of using Present Indefinite and Present Continuous in denoting future actions.

Example 1.

"This may be Atlantis's last flight but the launch will mark one first, as it carries the first iPhone into space" [12]. The sentence is about future action, since at the time of the speech, the launch of Atlantis has not taken place yet. The verb carries expresses the action of the future tense in relation to the present, it has the meaning of a clear planning of the action, the statement itself is categorical. The action of the future does not depend on the will or desire of the speaker, does not include a logical or emotional assessment, therefore its modality is objective. Let us note that in this example there are two means of expressing the future at once - will mark, it carries. In the first case (will mark) expresses the future action, but this is an assumption made by the speaker. The action of the future tense, expressed by the form carries, on the contrary, is not an assumption of the speaker, but an immutable fact.

Example 2.

"The new measures - which come into effect really soon - will stop alcohol being sold in unlicensed kiosks" [2].

Come into effect expresses the action of the future tense, the lexical marker of time indicates the situation of the future action, the present form has the meaning of the action's 
firm planning, the speaker's attitude to certain future events, there are no modal shades of desire or will in the description of the future event, i.e. action modality is objective. As in the previous example, we observe the use of two means of expressing the future, the second of which - will stop - denotes the anticipated future, an action that cannot be asserted, but can only be predicted.

Example 3.

"Being Human" returns next month on BBC America. Fans of the original BBC series Being Human, you won't have to wait that much longer for the third season to come to us!" [9].

Returns expresses the action of the future in relation to the present, the described situation has the meaning of the planned future action, knowledge of which is based on an external source - the schedule, while won't have to expresses the expected future action, the speaker's opinion, which does not depend on external factors, but his or her inner reflections.

Example 4.

"Oh, sir, please, just a minute. What shall we do?"

"Madam, I can't say. The army is evacuating Atlanta soon."

"Going off and leaving us to the Yankees?"

"I'm afraid so" [6, p. 191].

Is evacuating, going off, leaving express future action in relation to the present situation. The meaning of the form is a clearly planned action, the performance of which does not depend on the will or desire of the speaker, in other words, the action of the future is determined by external circumstances, therefore, the modality of the statement is objective, not including the semantics of the "inner self".

Example 5.

"What time are we meeting tomorrow?' I mumbled sheepishly.

'Eight-thirty. Cafe Rouge” [5, p.35].

Are meeting expresses the action of the near future to the situation of the present. We are talking about a planned meeting, the future action does not depend on the speaker's logical or emotional assessment of events and does not include the semantics of the "inner self," therefore the modality of the action is objective.

Basing on the theory and practical examples we can conclude that Present Indefinite and Present Continuous are used to express such future events, in the description of which there is no logical or emotional assessment on the part of the speaker. The action is planned, determined by the calendar; the external source of knowledge about it does not follow from the speaker's thoughts and does not include the semantics of his or her inner self.

$$
* * *
$$

1. Barkhudarov, L. Shtelling, D. English Grammar. M., 1993. - 423p.

2. BBC news. Europe. Russia classifies beer as being alcoholic: [Electronic resource] - Access mode: http://www.bbc.co.uk/news/world-europe-14232970 (dated 12.02.2021).

3. Bloch M.Ya. Theoretical Grammar. - M, 1986. - 159 p.

4. Chrisonopulo E.Yu. Cognitive aspect of Indefinite forms in expressing future actions // Quantitate linguistics and semantics. - M., 2001. - p. 200-206.

5. Fiedling H. Bridget Jones. The edge of reason. - London: Picador, 2004. - 436 p.

6. Mitchell M. Gone with the Wind - US: Hachette Book, 1993. -560 p.

7. Plotkin V.Ya. Grammar systems in the English language. - Kishinev, 1975. - 127 p.

8. Quirk R., Greenbaum S., Leech G., Svartvik J. A University Grammar of English. - M., 1982. - 391 p.

9. Stafeder L. Scifimania. Being Human Returns on BBC Next Month: [Electronic resource] - Access mode: http://scifimafia.com/2011/01/being-human-returns-next-month-on-bbc-america-with-season-threespoilers-inside/ (dated 08.03.2021).

10. Stepanov Yu.S. Names. Predicates. Sentences. - M.:, 1981. - 361 p.

11. Weikhman, G. New in the modern English Grammar: manual for universities. - M., 2002. - 554p.

12. Wilkins L., Jones A. BBC News. Atlantis Shuttle Launch: [Electronic resource] - Access mode: http://www.bbc.co.uk/news/science-environment-14076454 (dated 19.02.2021). 